\title{
An Analysis of Omission in Students' English Writings
}

\author{
Ingatan Gulö ${ }^{1}$, Teo Vany Rahmawelly ${ }^{2}$ \\ atan@teknokrat.ac.id ${ }^{1}$, teo.vani1608@gmail.com² \\ Universitas Teknokrat Indonesia ${ }^{1,2}$
}

\begin{abstract}
This paper is part of research with a larger scope covering errors students made related to subject-verb agreement. This part aims to elaborate grammatical problems faced by foreign language learners of English in relation to the omission they made in their writings. A qualitative data collection method was applied in gathering the data. The researchers collected pieces of writing from the students, read them, and analysed the omission errors found in the collected writings. As result, the most common omissions found in the data are related to verb markers. Omission of main verbs and auxiliaries also occur, creating sentences without any verbs or grammatically necessary auxiliaries. Absense of these kinds of function in Indonesian is the main reason for this grammatical problem faced by the learners. In addition, omissios of suffix -ing were also found by the researchers in the data. These findings should be able to contribute to existing works on grammatical errors and increase the success of both teaching and learning of a foreign language like English.
\end{abstract}

Key Words: error, grammar, omission, writing

\section{Introduction}

Writing is one of ways by which a foreign language learner's ability is evaluated. The sententes produced tell how much a particular learner has understood how a foreign language works. According to Harmer (2004: 33), "Writing is frequently useful as preparation for some other activities, in particular when students write sentences as a preamble to discussion activities". In other words, writing helps prepare students in broader aspects of learning activities. This means that a student's writing skill is not something that can be taken for granted by teachers. It is normal for students to make mistakes at the beginning but efforts should be made in order to prevent them from continuing the same mistakes or errors. Some differenciate mistakes from errors with many reasons but in this paper they are treated the same and are generally treated as grammatical problems faced by the students. Corder in Ellis (2008) maintain that an error is a deviation in learner's language which results from lack of knowledge of the correct rule. Therefore, error becomes common phenomena produced by students in written forms.

Patel (2015) argued that learners commit errors either because of inappropriate knowledge or false knowledge in the target language and learners needs to write correct sentences in English in order to convey their messages effectively to the readers. Related to this explanation, the writers maintain that learners have to understand grammatical sentences when writing. Moreover, Mbau stated that grammatical sentence means that the sentence should follow the rules of the language (2014: 2). Based on this, the writers argue that in forming a sentence, students must pay attention to subject and verb agreement. In writing, different tenses have different rules so the use of verb will be changed according to subject. Learners especially English students have to comprehend the rules well. If the students lack of conceiving the explication, it can cause errors of grammatical sentences dealing with subject-verb agreements. It can happen in a simple sentence like She run to the jungle instead of She runs to the jungle in present tense context. Therefore, learners have to understand the rules to make a correct sentence because learners at the beginning often make errors related to this.

Experts believed the importance of grammar also play role in achieving learners' educational and professional goals (Baleghzadeh \& Gordani, 2012). In learning English, there are four types of proficiencies, they are listening, reading, speaking and writing. Therefore, the importance of grammar will give many benefits that will encourage the knowledge of the students who are learning to foster their skill about English especially in writing correct sentences. Supporting that, this paper focuses on writing because it is one of English skills which often deal with grammatical errors made by students. Based on the writers' observation on the students' academic written works, there were incorrect sentences caused by omissions. Therefore, the writers investigated those pieces of writing further in order to make improvements in teaching and learning process and thus students are able to make correct sentences. 


\section{Theory and Method}

Subject and verb are always related to each other because a construction cannot fully portray a proposition if there is only subject; no verb. It cannot be called a sentence. Berkham (2015) states that the subject of a sentence is the noun that corresponds with the verb in the sentence. It means that in relation to the presence of subject and verb when producing grammatical sentences, they both have to be in the right structure. Berkham also says that subject-verb agreement is a rule that states that all subjects must agree with their verbs in number (2015). Agreement in sentences depends on the number of subject that will influence the form of verb in sentences.

Tense is a verb based method to express the distinctions of time and indicate the action when taking place: past, present, future, or perfect. According to Rozakis (2003), by seeing the form of a verb, the reader may find out the tenses as the rules of subject-verb agreement that cover subject, verb, numbers, etc. In tenses, there are two possibilities to determine the verb in action: "person and number". Person is who experiences the action that determines the subject as a noun in sentences. Number determines how many subjects act or receive the action. Number agreement poses a problem in the present tense, where third person singular are explicitly inflected while others forms are not.

In analyzing the data, the method of the study used by the writers was qualitative method (Kothari, 2004; Stake 2010. According to Hancock, qualitative research method is concerned with developing explanation that focuses on description and interpretation (2002). In other words, descriptive qualitative is a method used to study and analyze the collected data by using some relevant approaches which structured or written as in descriptive.

Since the data are in the form of sentences, the findings are describes in the form of words rather than numbers. The researchers collected pieces of writing from the students, read them, and analysed the omission errors found in the collected writings. Having made a conclusion, the writers then report the result in this paper.

\section{Findings and Discussion}

Omissions found in the data cover various gammatical issues. The data analyzed show that foreign language learners often omit singular verb markers, verbs, auxiliaries, and suffix -ing on verbs. These will be discussed one by one under relevant topics.

\section{Ommision of Singular Verb Markers}

After analyzing the data, the researchers found out that most of the problems faced by the students related to ommision is about singular verb marker $-s$ or $-e s$. This deals with the present tense rules which are really important in learning English as the tense is used in every day communication. Some examples are presented here:
No. Data
1. My father always support me
2. He wear glasses
3. She always stay home

\author{
Omission \\ Omission of ending $-s$ \\ Omission of ending $-s$ \\ Omission of ending $-s$
}

The writers found 95 cases dealing with ending $-s$ and es but the writer took only 3 examples to present here as they all display the same characteristics. As shown in the examples above, the students have a problem with the basic rule of subject-verb agreement as stated by Greenbaum and Nelson in Chele in which a verb should match the number of subject (2015). In the first data, the noun phrase my father is in singular form. Based on the rule of subject-verb agreement, singular subject take singular verb and plural subject take plural verb. In this data, the verb is in the plural form and should be added $-s$ to its end becoming supports in order to make it agree with the preceeding subject.

In the second one, the same case repeats. The subject $\mathrm{He}$ refers to singular form and needs the singular form of verb. Therefore, the verb should be wears. In the third one the case is the same with the others; it needs ending -es to match with the rule. The verb should be stays.

These data indicate that the learners tend to omit verbal suffixes and this makes the verbs not agree with the subjects in the sentences. The next analysis still has a relation to problems of subject-verb agreement but with a more complex grammatical rule.
No. Data
4. She always cry
5. She study hard but not success

\author{
Omission \\ Omission of ending -es \\ Omission of ending -es
}


6. A student often go to the library Omission of ending -es

Based on the examples given above, the omission of ending $-s$ occurs very often in the data. The learners have problems in matching singular verb with singular subject. The verb cry in datum 4 is in plural form and thus does not agree with the singular subject She that precedes the verb. It must be in the third person singular form with ending -es, so the verb is cries not cry.

The second datum occurs in the same way. The verb study is in plural form that it does not agree with the singular form of the subject She. In order for the sentence to be grammatically correct, the verb must be changed from cry to cries. By doing this, the student has made the verb agree with the subject. In the last datum another very common error occurs as the verb $g o$ is in incorrect form. As the subject $A$ student is in singular form, the form of verb needed should be singular as well. Thus the verb go should be changed into goes in order to have a structurally acceptable sentence.

Comparing to those of the first group in 1-3, the sentences in the second one are grammatically more complex. In addition to the fact that the letter $-y$ that closes the the ends of the verbs should be changed into $-i$ before adding suffix -es, adverbs always and often are also employed (like in 4 and 6) and this might contribute to the learners' inability to realise that they have to match the verbs with the subjects. Looking at number 5 and 2 , however, this conclusion is arguable.

\section{Omission of Verbs}

The writers found 10 data related to error in using verbs. The students often omit verbs when they produce sentences in nominal forms.

No. Data

$7 \quad$ She $\varnothing$ very beautiful

8. $\quad$ He $\varnothing 22$ years old

9. He passed away when I $\varnothing$ child

10. I $\varnothing$ angry with her

\author{
Omission \\ Omission of verb is \\ Omission of verb is \\ Omission of verb was \\ Omission of verb was
}

From these four data above, it is obvious that the verbs being the main parts of the sentences, or the last clause in 9, are omitted. In 7 and 8, the verb is is absent from both sentences. In order for the constructions to be grammatically correct, they must be changed into She is very beautiful and He is 22 years old. In 9 and 10, the verb was as the past form of is is also absent from the constructions. Number 10 has to be I was angry with her and the last clause of 9 must be changed into I was a child. However the learners are not aware of the importance of these verbs in English sentences.

Comparing these to Indonesian linguistics, the writers strongly suggest that one of the reasons why English learners have difficulties in making this type of sentence is because in Bahasa, equivalent constructions of those above are made without any verbs. In datum 7, for example, the sentence will do just fine by having a personal pronoun Dia 'She' with an adjective phrase sangat cantik 'very beautiful'. There is no verb in the sentence. In the second clause of datum 9, the same principle applies. Having a personal pronoun Saya for I and either a more literally translated noun phrase anak kecil or a more natural translation of adjective phrase masih kecil is enough. No verb is needed in making such constructions.

\section{Ommision of Auxiliary Verbs}

Sometimes the students do not omit the main verbs when creating their sentences. The problem they face is about the use of auxiliary verbs that are necessary to show the tense or the voice of the sentences. In the following data, for instance, the main verbs are present but the auxiliaries are not.

No. Data

11. The girl crying when I come

12. They waiting for you

\section{Omission \\ Omission of auxiliary verb was Omission of auxiliary verb are}

From the study conducted by the researchers, $45 \%$ of the students made mistakes about this. It is suggested here that this is caused by the fact that in Indonesian, the students' linguistic background, the presence of this kind of auxiliary is not grammatically required. In Indonesian, both was and are above are replaced by sedang which tells that the action told by a following verb is in progress. Sedang, however, does not carry with it the same linguistic functions as was and are do. It has important semantic content in the sentence (Sneddon, 1996, 2000). In 
English, in contrary, was and are are really needed even if they carry almost no semantic content. These two words required in number 11 and 12 above carry functional notions with them, telling the time and the nature of the sentences. A similar case occurs in the examples provided below.

$\begin{array}{ll}\text { No. } & \text { Data } \\ \text { 13. } & \text { He not live in Lampung } \\ 14 . & \text { He not think }\end{array}$

An auxiliary does is absent from the sentences above. This problem faced by English learners is also contributed by their mother tongue where in Indonesian, 13 and 14 will be Dia tidak tinggal di Lampung and Dia tidak berpikir respectively. Both of these Indonesian sentences have got their word for word corresponding words to those of English sentences: Dia for He, tidak for not, tinggal and berpikir for live and think, and di Lampung for in Lampung. From this perspective of an Indonesian speaker learning English, no linguistic element is missing in order to grammatically convey the message. In English, of course, that is not how it works. Auxiliary does is needed.

\section{Omission of Ending -ing}

The last case of omission presented here is related to suffix -ing especially when the word it is attached to functions as verb. From around $20 \%$ occurence in the data, four are provide here to be discussed.

$\begin{array}{ll}\text { No. } & \text { Data } \\ \text { 15. } & \text { Now Elsa is study in Jogja } \\ \text { 16. } & \text { She was watch TV } \\ \text { 17. } & \text { When I was talk with her, ... } \\ \text { 18. } & \text { Are you talk to right person? }\end{array}$

All of those main verbs above are not in the right forms of English grammatical structure. Number 15 and 16 have already had their auxiliaries is and was which indicate that the verbs following them should be in -ing form. However, it is seen from the data that the students use verbs in simple form instead. The same case occurs in 17 and 18 in which different students have already used was and are to indicate that the actions carried by following verbs are in progress but they failed to realize that the verbs should be in correct forms as well.

In order for the sentences to be grammatically correct, the correct form of the verbs should be in present participle or -ing form which are respectively studying, watching, talking and talking. It is also seen from the examples provided that the students made other grammatical mistakes. The first is that the preposition with in 17 should be changed to to and number 18 needs an article the between the preposition to and the adjective right.

\section{Conclusion}

The most common omissions found in the data are related to verb markers $-s$ and -es, verbs, auxiliaries, and -ing form. That of suffix $-s$ or -es is also actually omitted by the students when it functions as a plural marker but in the data obtained by the researchers this does not occur very often. The omission of verbs occur only in nominal sentences because in Indonesian, other word categories such as adjective and noun can function as predicates, creating sentences without any verbs. Auxiliary omission occurring in the data is related to continuous or progressive tenses. Absense of this kind of function in Indonesian is the main reason for occurrence of this grammatical problem faced by the learners. Omission of suffix -ing found by the researchers occur when verbs in their present participle function as verbs, not as adjectives.

\section{References}

Baleghizadeh, Sasan \& Yahya Gordani. 2012. Academic writing and grammatical accuracy: the role of corrective feedback. Gist Education \& Learning Research Journal, No. 6, 159-176.

Berkham, Justin. 2015. Subject-verb Agreement. Retrieved from :http://blog.prepscholar.com/subject-verbagreement-for-act-english.

Chele, Mampoi Irene. 2015. An analysis of subject-verb agreement error in English: the case of the third year students at The National University of Lesotho. Ghana Journal of Linguistics, Vol. 4. No. 1.

Ellis, R. and G. Barkhuizen. 2005. Analysing Learner Language. Oxford: Oxford University Press. 
Hancock, Beverly. 2009. An Introduction to Qualitative Research. University of Nottingham: Trent Focus Group.

Harmer, Jeremy. (2004). How to Teach Writing. England: Longman.

Kothari, C.R. 2004. Research Methodology: Methods and Techniques. New Delhi: New Age International Publishers.

Mbau, Anitha Thalib et al. 2014. An analysis of subject-verb agreement error in writing paragraph made by the second semester students at English Department. English Language Teaching Society (ELTS), Vol. 2(2).

Patel, Sejal. 2015. The scenario and impact of English teaching in technical education of India. The Global Journal of English Studies, Vol. 2 (1), September 2015.

Rozakis, Laurie. 2003. English Grammar for the Utterly Confused. New York: McGraw-Hill.

Sneddon, James Neil. 1996. Indonesian: A Comprehensive Grammar. London: Routledge.

Sneddon, James Neil. 2000. Indonesian Reference Grammar. Melbourne: University of Sydney.

Stake, Robert E. 2010. Qualitative Research: Studying How Things Work. New York: The Guilford Press. 